\title{
Deaths among the elderly with ICU infections
}

\author{
Óbitos em idosos com infecção adquirida em Unidades de Terapia Intensiva \\ Muertes en ancianos con infecciones adquiridas en Unidades de Terapia Intensiva
}

\begin{abstract}
Álvaro Francisco Lopes de Sousa', Artur Acelino Francisco Luz Nunes Queiroz', Layze Braz de Oliveira', Luana Kelle Batista Moura", Denise de Andrade', Evandro Watanabe', Maria Eliete Batista Moura'I"

' Universidade de São Paulo, Nursing School of Ribeirão Preto, Postgaduate Program in Fundamental Nursing. Ribeirão Preto, São Paulo, Brazil.

"Centro Universitário UNINOVAFAPI, Postgraduate Program in Family Health. Teresina, Piauí, Brazil.

II' Universidade Federal do Piauí, Health Science Center, Postgraduate Program in Nursing. Teresina, Piauí, Brazil.
\end{abstract}

How to cite this article:

Sousa AFL, Queiroz AAFLN, Oliveira LB, Moura LKB, Andrade D, Watanabe E, Moura MEB. Deaths among the elderly with ICU infections. Rev Bras Enferm [Internet]. 2017;70(4):733-9. [Thematic Edition "Good Practices: Fundamentals of care in Gerontological Nursing"] DOI: http://dx.doi.org/ 10.1590/0034-7167-2016-0611

Submission: 12-19-2016 Approval: 02-22-2017

\section{ABSTRACT}

Objective: to evaluate the clinical outcome of elderly patients admitted to intensive care units who had nosocomial infection, correlating the findings with sociodemographic and clinical variables. Method: descriptive research, performed with 308 elderly patients. The collection was made from medical records and covers the years 2012 to 2015. Uni-/bivariate analyses were performed. Results: a statistical association was found between the clinical outcome types and the variables age, length of stay, presence of previous comorbidities, main diagnosis, respiratory and urinary tract infections, use of central venous and indwelling urinary catheters, mechanical ventilation, and tracheostomy. The survival curve showed higher mortality among the elderly from the age of 80 on. Conclusion: the clinical outcome of the elderly who acquire infection in the intensive care unit is influenced by sociodemographic and clinical variables that increase mortality rates.

Descriptors: Infection; Elderly; Clinical Outcome; Death; Intensive Care Units.

\section{RESUMO}

Objetivo: avaliar o desfecho clínico de idosos que adquiriram infecção hospitalar hospitalizados em Unidades de Terapia Intensiva, correlacionando os achados com variáveis sociodemográficas e clínicas. Método: pesquisa descritiva, realizada com 308 pacientes idosos. A coleta deu-se em prontuários e contempla os anos de 2012 a 2015 . Realizaram-se análises uni-/bivariadas. Resultados: registrou-se associação estatística entre os tipos de desfechos clínicos e as variáveis: faixa etária, tempo de internação, presença de comorbidades prévias, diagnóstico principal, infecção do trato respiratório e urinário, uso de cateteres vesical de demora e venoso central, ventilação mecânica e traqueostomia. A curva de sobrevivência evidenciou maior mortalidade entre idosos a partir de 80 anos. Conclusão: o desfecho clínico de idosos que adquirem infecção na Unidade de Terapia Intensiva é influenciado por variáveis sociodemográficas e clínicas, que incrementam as taxas de mortalidade.

Descritores: Infecção; Idoso; Desfecho clínico; Óbito; Unidades de Terapia Intensiva.

\section{RESUMEN}

Objetivo: evaluar el desenlace clínico de ancianos que adquirieron infección intrahospitalaria durante internación en Unidades de Terapia Intensiva, correlacionando los hallazgos con variables sociodemográficas y clínicas. Método: investigación descriptiva, realizada con 308 pacientes ancianos. Datos recolectados de historias clínicas, considerando los años de 2012 a 2015. Se realizaron análisis uni/bivariados. Resultados: se registró asociación estadística entre los tipos de desenlace clínico y las variables: faja etaria, tiempo de internación, presencia de comorbilidades previas, diagnóstico principal, infección del tracto respiratorio y urinario, uso de catéteres vesicales de demora y venoso central, ventilación mecánica y traqueotomía. La curva de supervivencia evidenció mayor mortalidad entre ancianos a partir de los 80 años. Conclusión: el desenlace clínico de ancianos que adquieren infecciones en Unidades de Terapia Intensiva es influenciado por variables sociodemográficas y clínicas, que incrementan las tasas de mortalidad.

Descriptores: Infección; Anciano; Desenlace Clínico; Muerte; Unidades de Cuidados Intensivos.

\section{CORRESPONDING AUTHOR \\ Alvaro Francisco Lopes de Sousa \\ Email: alvarosousa@usp.br}




\section{INTRODUCTION}

Hospital infections are an important public health problem, especially when they involve the elderly, the group with the highest rates of population growth in most countries ${ }^{(1-3)}$. The hospitalization of the elderly has higher importance when these patients' clinical condition is critical, requiring greater demand for care.

In intensive care units (ICUs), hospitalizations have increased annually, and are related to diagnoses ranging from exacerbations of chronic diseases to trauma of greater impact and/or accidents ${ }^{(2,4)}$.

Hospital infection is one of the most serious health risks to the elderly in the ICU. It is predominant in extremes of age, and related to intrinsic and exogenous factors, such as medical diagnosis, environment, and length of stay, among other variables ${ }^{(4-5)}$. Research on this topic is still sparse in Latin American literature, which makes it difficult to establish the real situation in terms of prevalence and main sites affected. Thus, the combination of these factors influences the patient's stay in the ICU, being determinant for the outcome of hospitalization or the clinical outcome (discharge) ${ }^{(6-7)}$.

This study aimed to evaluate the clinical outcome of the elderly who had nosocomial infection in intensive care units, correlating the findings with sociodemographic and clinical variables.

\section{METHOD}

\section{Ethical aspects}

The research development complied with national and international standards of research ethics involving human subjects and was approved by the Research Ethics Committee.

\section{Study design, setting, and period}

This is a cross-sectional survey, with retrospective data collection, performed in exclusively adult intensive care units of a large public reference hospital in the Northeastern region of Brazil. The hospital experiences about 200,000 (clinical and surgical) annual visits in several specialties. The collection included the two ICUs of the service, which have a total of 15 beds and an average hospitalization of 80 patients per month. Most patients are admitted postoperatively following major surgeries.

The study population consisted of elderly patients (60 years old or over) hospitalized in the ICUs of the health service investigated, from January 2012 to June 2015, who developed hospital infection, according to the criteria of the Centers for Disease Control and Prevention $(\mathrm{CDC})^{(8)}$ and the Brazilian Health Regulatory Agency (ANVISA) ${ }^{(9)}$.

\section{Sampling and inclusion and exclusion criteria}

A total of 308 elderly patients were included in the sample because they met the inclusion criteria: age equal to or over 60 years; with diagnosis of hospital infection after admission to the ICU. Exclusion criteria were: lack of accuracy in records regarding socioeconomic information; infection topography; invasive procedures; antibiotics; and clinical outcome in the ICU.

\section{Study protocol}

The collection was done using medical records and the database of the Hospital Infection Control Commission $(\mathrm{CCIH})$ of the hospital. A structured formulary was used, with information on sociodemographic variables (gender, age, place of birth, and occupation), topographic site of infections, preexisting diseases, main diagnosis for admission, use of invasive procedures, and hospitalization clinical outcome (type of discharge). The criteria for discharge from the ICU of the investigated service were considered, classified into: 1) Improved: discharge due to recovery of the clinical condition; 2) Death; and 3) Transferred: discharged from the ICU through transfer to another medical service.

The instrument used was previously validated by five experts in the area, using a Likert scale ${ }^{(10)}$ as consensus. A consensus criterion was established that the item had to achieve a minimal percentage of $75 \%$ of record in "important" or "very important" scores in order to remain in the questionnaire.

\section{Analysis of results and statistics}

Data were entered using Excel software, double typing, and later validation; they were analyzed using the Statistical Package for Social Sciences (SPSS) application, version 20.0. The Kolmogorov-Smirnov test was used to evaluate the normality of the distribution of variables. To check the association between the clinical outcome and the variables of the research, descriptive univariate and bivariate analyses were performed. For categorical variables, the chi-square test was used and the level of significance was set at $p \leq 0.05$ with a $95 \%$ confidence interval. We also used the Kaplan-Meier method to analyze survival.

\section{RESULTS}

This study registered a prevalence of women (181/58.8\%) and a mean age of 71 years ( \pm 8.5 years), with a maximum age of 97 years. Among the previous comorbidities, hypertension prevailed (99/32.1\%). The main reason for the ICU stay was related to the postoperative period of fracture(s) (126/40.9\%).

There was a statistical association between the clinical outcome and the variables: age group ( $p=0.045)$; time or period of ICU stay ( $p<0.01)$; presence of prior comorbidities $(p=0.03)$; and main diagnosis for the current hospitalization $(p=0.01)$ (Table 1).

Table 2 shows the distribution of different types of clinical outcome, relating them to topographies: Respiratory infection ( $p=0.002)$, Urinary tract infection ( $p=0.045)$, Bloodstream infection ( $p=0.298)$, and Infection of surgical site ( $p$ $=1.000)$. All patients developed infection on at least one of the topographic sites.

All patients underwent at least one invasive procedure. Regarding the types, the indwelling vesical catheter $(p<0.001)$, the endotracheal tube ( $p=0.001)$, tracheostomy $(p=0.001)$ and central venous access prevailed ( $p=0.007$ ) (Table 3 ). 
Table 1 - Distribution of types of clinical outcomes in the elderly with diagnosis of infection hospitalized in Intensive Care Units according to sociodemographic variables, Teresina, Piauí, Brazil, 2012-2015

\begin{tabular}{|c|c|c|c|c|c|c|c|c|c|}
\hline & \multicolumn{8}{|c|}{ Clinical outcome } & \multirow{3}{*}{$p$ value* } \\
\hline & \multicolumn{2}{|c|}{ Improved } & \multicolumn{2}{|c|}{ Transference } & \multicolumn{2}{|c|}{ Death } & \multicolumn{2}{|c|}{ Total } & \\
\hline & $\mathbf{n}$ & $\%$ & $\mathbf{n}$ & $\%$ & $\mathbf{n}$ & $\%$ & $\mathbf{n}$ & $\%$ & \\
\hline Total & 120 & 39.0 & 31 & 10.1 & 157 & 50.9 & 308 & 100.0 & \\
\hline Gender & & & & & & & & & 0.233 \\
\hline Male & 55 & 43.3 & 11 & 8.7 & 61 & 48.0 & 127 & 41.2 & \\
\hline Female & 65 & 36.0 & 20 & 11.0 & 96 & 53.0 & 181 & 58.8 & \\
\hline Age range & & & & & & & & & 0.045 \\
\hline 60 to 69 years & 67 & 43.0 & 16 & 10.2 & 73 & 46.8 & 156 & 50.6 & \\
\hline 70 to 79 years & 39 & 41.0 & 9 & 9.5 & 47 & 49.5 & 95 & 30.9 & \\
\hline 80 years on & 14 & 24.6 & 6 & 10.5 & 37 & 64.9 & 57 & 18.5 & \\
\hline Time of stay & & & & & & & & & $<0.001$ \\
\hline 1-10 days & 62 & 44.6 & 4 & 2.9 & 73 & 52.5 & 139 & 45.2 & \\
\hline 11-20 days & 20 & 26.7 & 18 & 24 & 37 & 49.3 & 75 & 24.3 & \\
\hline 21-30 days & 18 & 40.9 & 6 & 13.6 & 20 & 45.5 & 44 & 14.3 & \\
\hline $31-40$ days & 5 & 16.7 & 3 & 10.0 & 22 & 73.3 & 30 & 9.7 & \\
\hline 41 or more days & 15 & 75.0 & 0 & 0 & 5.0 & 25.0 & 20 & 6.5 & \\
\hline Associated comorbidities $* *$ & & & & & & & & & 0.003 \\
\hline Hypertension & 42 & 40.8 & 8 & 7.8 & 53 & 51.4 & 103 & 33.4 & \\
\hline Diabetes & 14 & 32.5 & 11 & 25.6 & 18 & 41.9 & 43 & 14.0 & \\
\hline Chronic renal insufficiency & 24 & 34.3 & 13 & 18.6 & 33 & 47.1 & 70 & 22.7 & \\
\hline Cardiopathies & 13 & 35.1 & 7 & 18.9 & 17 & 46.0 & 37 & 12.0 & \\
\hline Obesity & 12 & 46.1 & 6 & 23.1 & 8 & 30.8 & 26 & 8.4 & \\
\hline Others & 25 & 44.6 & 4 & 7.1 & 27 & 48.3 & 56 & 18.1 & \\
\hline Main diagnosis & & & & & & & & & 0.001 \\
\hline Limb fracture & 41 & 32.6 & 12 & 9.5 & 73 & 57.9 & 126 & 40.9 & \\
\hline Neoplasias & 22 & 50.0 & 7 & 15.9 & 15 & 34.0 & 44 & 14.3 & \\
\hline Treatment of liver diseases & 19 & 41.3 & 10 & 21.7 & 17 & 37.0 & 46 & 14.9 & \\
\hline Treatment of cardiovascular diseases & 14 & 30.4 & 3 & 6.5 & 29 & 63.1 & 46 & 14.9 & \\
\hline Treatment of neurological diseases & 7 & 33.3 & 2 & 9.5 & 12 & 57.2 & 21 & 6.8 & \\
\hline Treatment of respiratory diseases & 14 & 56.0 & 1 & 4.0 & 10 & 40.0 & 25 & 8.2 & \\
\hline
\end{tabular}

Note: $*$ Statistical significance was set at $p \leq 0.05 ; * *$ It does not sum $100 \%$, because patients could have more than one associated comorbidity.

Table 2 - Distribution of types of clinical outcome in the elderly with a diagnosis of infection in intensive care units, according to the topographic site of infection, Teresina, Piauí, Brazil, 2012-2015

\begin{tabular}{|c|c|c|c|c|c|c|c|c|c|}
\hline \multirow{3}{*}{ Topography } & \multicolumn{8}{|c|}{ Clinical outcome } & \multirow{3}{*}{$p$ value* } \\
\hline & \multicolumn{2}{|c|}{ Improved } & \multicolumn{2}{|c|}{ Transference } & \multicolumn{2}{|c|}{ Death } & \multicolumn{2}{|c|}{ Total } & \\
\hline & $\mathbf{n}$ & $\%$ & $\mathrm{n}$ & $\%$ & $\mathbf{n}$ & $\%$ & $\mathrm{n}$ & $\%$ & \\
\hline Total & 120 & 39.0 & 31 & 10.0 & 157 & 51.0 & 308 & 100 & \\
\hline Respiratory tract infection & & & & & & & & & 0.002 \\
\hline Yes & 49 & 32.0 & 16 & 10.5 & 88 & 57.5 & 153 & 49.7 & \\
\hline No & 71 & 45.8 & 15 & 9.7 & 69 & 44.5 & 155 & 50.3 & \\
\hline Urinary tract infection & & & & & & & & & 0.045 \\
\hline Yes & 48 & 46.1 & 6 & 5.8 & 50 & 48.1 & 104 & 33.8 & \\
\hline No & 72 & 35.3 & 25 & 12.3 & 107 & 52.4 & 204 & 66.2 & \\
\hline Bloodstream Infection & & & & & & & & & 0.298 \\
\hline Yes & 30 & 32.3 & 12 & 10.7 & 47 & 57.0 & 89 & 21.1 & \\
\hline No & 90 & 40.7 & 19 & 9.9 & 110 & 49.4 & 219 & 78.9 & \\
\hline Surgical site infection & & & & & & & & & $1.000 * *$ \\
\hline Yes & 6 & 40.0 & 1 & 6.7 & 8 & 53.3 & 15 & 4.9 & \\
\hline No & 114 & 38.9 & 30 & 10.2 & 149 & 50.9 & 293 & 95.1 & \\
\hline
\end{tabular}

Note: *Statistical significance was set at $p \leq 0.05 ; * *$ Fischer's exact test. 
Table 3 - Distribution of types of clinical outcome in the elderly with a diagnosis of infection admitted to intensive care units, according to the use of invasive procedures, Teresina, Piauí, Brazil, 2012-2015

\begin{tabular}{|c|c|c|c|c|c|c|c|c|c|}
\hline \multirow{3}{*}{ Use of invasive procedures } & \multicolumn{8}{|c|}{ Clinical outcome } & \multirow{3}{*}{$p$ value* } \\
\hline & \multicolumn{2}{|c|}{ Improved } & \multicolumn{2}{|c|}{ Transference } & \multicolumn{2}{|c|}{ Death } & \multicolumn{2}{|c|}{ Total } & \\
\hline & $\mathbf{n}$ & $\%$ & $\mathbf{n}$ & $\%$ & $\mathbf{n}$ & $\%$ & $\mathbf{n}$ & $\%$ & \\
\hline Total & 120 & 39.0 & 31 & 10.0 & 157 & 51.0 & 308 & 100 & \\
\hline Nasogastric/nasoenteral tube & & & & & & & & & 0.290 \\
\hline Yes & 70 & 38.0 & 15 & 8.2 & 99 & 53.8 & 184 & 59.7 & \\
\hline No & 50 & 40.3 & 16 & 12.9 & 58 & 46.8 & 124 & 40.3 & \\
\hline Indwelling vesical catheter & & & & & & & & & $<0.001$ \\
\hline Yes & 83 & 32.8 & 23 & 9.1 & 147 & 58.1 & 253 & 82.1 & \\
\hline No & 37 & 67.3 & 8 & 14.5 & 10 & 18.2 & 55 & 17.9 & \\
\hline Endotracheal tube & & & & & & & & & 0.001 \\
\hline Yes & 80 & 52.3 & 14 & 9.1 & 59 & 38.6 & 153 & 49.7 & \\
\hline No & 68 & 43.9 & 17 & 11.0 & 70 & 45.1 & 155 & 50.3 & \\
\hline Tracheostomy & & & & & & & & & 0.001 \\
\hline Yes & 33 & 27.3 & 18 & 14.9 & 70 & 57.8 & 121 & 39.3 & \\
\hline No & 87 & 46.5 & 13 & 7.0 & 87 & 46.5 & 187 & 60.7 & \\
\hline Ventral venous access & & & & & & & & & 0.007 \\
\hline Yes & 43 & 53.7 & 7 & 8.8 & 30 & 37.5 & 80 & 26.0 & \\
\hline No & 77 & 33.8 & 25 & 11.0 & 126 & 55.2 & 228 & 74.0 & \\
\hline
\end{tabular}

Note: *Statistical significance was set at $p \leq 0.05$.

According to the Kaplan-Meier survival curve, hospital mortality in the elderly who developed ICU infection does not have large variations among either the delimited age groups or the discharge types. However, it should be taken into account that the elderly aged 80 years and over presented death as a clinical outcome, mainly due to the prolonged hospitalization time (Figure 1).

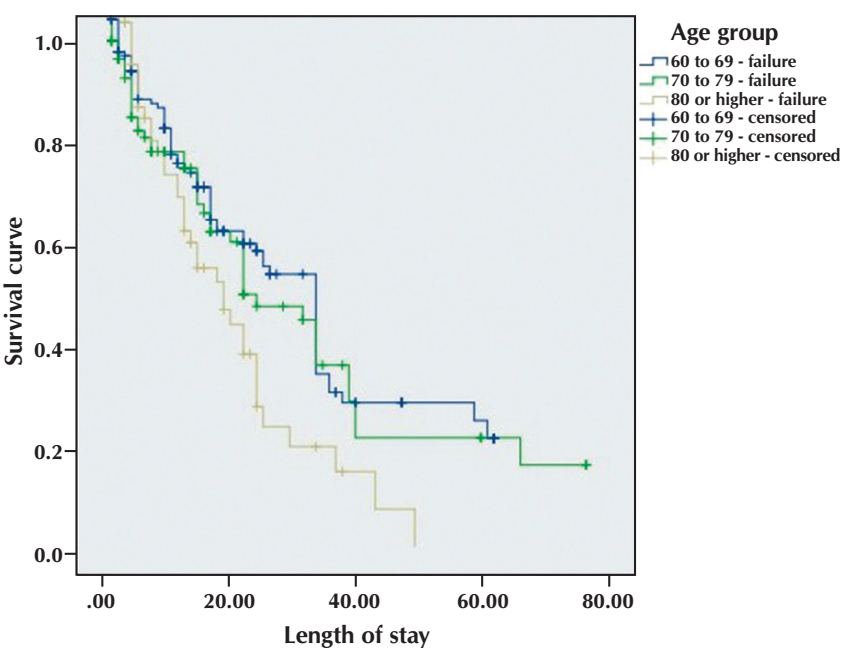

Figure 1 - Kaplan-Meier curve, indicating hospital mortality according to age, Teresina, Piauí, Brazil, 2012-2015

\section{DISCUSSION}

In this research, sociodemographic and clinical characteristics influenced the clinical outcome of the elderly with infection in the ICU, contributing to a high death rate. These findings corroborate that factors associated with hospitalization should be identified and treated early, especially in patients with advanced age, because complications can lead to generalized infection with a consequent increase in mortality.

Among the sociodemographic variables related to the elderly in this study, the higher proportion of women is highlighted. Because they have a higher prevalence of chronic diseases, women seek care in health institutions more spontaneously than men. In addition, males are associated with high mortality in adulthood (20 to 29 years), which contributes to greater gender difference among the elderly ${ }^{(4)}$.

With regard to hospital infection in the elderly in Brazil, there is a research gap, especially when it involves the age range over 80 years. Researches that study the profile of patients who develop infection tend to generalize the findings by extrapolating them, disregarding the intrinsic characteristics of this population, while international research tends to study long-term care facilities, with less research in hospitals, especially in intensive care units ${ }^{(11)}$.

Old age alone is an independent risk factor for in-hospital mortality ${ }^{(12)}$. In Brazil, similarly to other developing countries, people aged 60 years or older represent the segment of the 
population with the greatest growth, reflecting the demographic transition that has an impact on the epidemiological profile, with the reduction of infectious, transmissible, and parasitic diseases, and an increase of chronic and degenerative diseases, such as hypertension, renal failure, diabetes mellitus, obesity, and neurological and cardiovascular diseases, among others. The progress or exacerbation of these diseases is usually accompanied by frequent hospitalizations requiring more serious interventions and long periods in a hospital setting ${ }^{(13)}$.

It is estimated that the number of hospitalized elderly patients will double in the coming decades around the world, especially among those of a more advanced age ${ }^{(6)}$. Due to this increase, elderly patients are frequently admitted to the most critical services with varied and often severe diagnoses ${ }^{(4,14-16)}$.

In elderly patients admitted to the ICU, changes in morphological and physiological variables should be considered, because they affect various organic functions, especially immunity, which makes patients even more vulnerable to infections, and may cause an extension of hospitalization under the use of invasive procedures, an increase in expenses with the treatment, and a rise in chances of death ${ }^{(16-17)}$.

Because it is considered a critical area, length of stay in the ICU influences the stay and the clinical outcome of the elderly. In this study, the highest number of deaths, when compared to hospitalization time, occurred exactly in the period longer than 30 days, which corroborates findings from another multicenter study ${ }^{(18)}$.

Longer hospitalization time will be reflected in prolonged use of invasive procedures, as well as increased stay in a critical environment. These procedures are known to be vital in the prolongation of life; however, they are commonly related to an increased risk of clinical complications ${ }^{(19-20)}$.

Elderly patients are more likely to present atypical manifestations and symptoms resulting from the onset of the infectious process, ranging from malaise and febrile peaks to delirium, disorientation, weakness, anorexia, or urinary incontinence, which may mask and delay the correct diagnosis ${ }^{(21-22)}$. In these cases, it is common to consider these clinical signs and symptoms as "arising from the aging process," which leads to the use of invasive procedures, especially indwelling urinary catheters and nasogastric tubes, in order to maintain organic function, obscuring the correct diagnosis even more ${ }^{(22-23)}$.

Among the different topographies, respiratory tract infections (RTIs) were the most frequent occurrence in this study. Pneumonia stands out among the RTIs, having a topography of higher prevalence in critical patients. The use of mechanical ventilation in the elderly causes a greater degree of dependence and an index of associated comorbidities in the post-hospitalization period, with emphasis on cardiovascular and neurological pathologies associated with higher severity scores ${ }^{(23)}$.

The elderly in intensive care units commonly present alterations in genitourinary function, especially among women over 80 years, which justifies the high use of indwelling urinary catheters, and explains the high rates of urinary tract infection. The diagnosis of urinary infection in the elderly depends to a great extent on the presence of clinical signs and symptoms; however, it should be confirmed through urine culture for treatment to be initiated ${ }^{(24-26)}$.

There are few comprehensive studies that investigate bloodstream infections among the elderly in the ICU, especially in Latin America. It is believed that the prevalence of bloodstream infection increases significantly over time among older people, leading to an increase in mortality rates, mainly due to late diagnosis or even underreporting. The use of catheters, especially central venous catheters, constitutes a considerable risk factor for infection because it provides direct access to the bloodstream, as it breaks the body's natural barriers ${ }^{(18,27-28)}$.

The highest number of deaths occurred in patients who had treatment of cardiovascular disease as the main diagnosis for admission. The occurrence of nosocomial infection in the postoperative period of cardiac surgeries presents a variable incidence (between $5 \%$ and $25 \%$ ), and there is no consensus on the actual death rates ${ }^{(29-30)}$.

In general terms, factors associated with hospital infection in the elderly in the ICU should be identified and treated early, as they may influence not only patients' stay in this environment, but also their clinical outcome (discharge). In spite of this, systematized perioperative attention focused on the identification of risk factors, such as age and preexisting diseases, as well as clinical variables, can directly interfere in the reduction of invasive procedures and the epidemiology of infection in ICUs.

\section{Limitations and contributions to public health}

This research has some limitations, mainly caused by the methodological design used (cross-sectional), which does not allow a follow-up of the elderly from the ICU to post-discharge care. In addition, data show the ICU of a single health facility, which may limit generalization of the findings. Data analysis was limited to the variables presented, because they were consolidated in the evaluation of risk factors for nosocomial infection, even though there are other covariables that may be of interest. Due to possible inaccuracies in information, we opted to cross-check the results of the different registry services, minimizing bias. Research that addresses hospital infection is necessary and feasible because, as demonstrated, more elderly people are being admitted to the ICU.

\section{CONCLUSION}

The clinical outcome of the elderly who acquire an infection in the intensive care unit is influenced by sociodemographic (age, length of stay, presence of preexisting comorbidities) and clinical (main diagnosis for hospitalization, topography of hospital infection, and use of invasive procedures) variables, with a greater impact on those aged 80 years or older who, consequently, have a higher death rate.

Thus, individualization of the service provided to the elderly in critical condition, observing the specific signs and symptoms and correlating them with the presence of infection, is essential. 


\section{REFERENCES}

1. Allegranzi B, Nejad SB, Combescure C, Graafmans W, Attar H, Donaldson L, et al. Burden of endemic health-care-associated infection in developing countries: systematic review and meta-analysis. Lancet [Internet]. 2011 [cited 2016 Oct 13];377(9761):228-41. Available from: https://www.ncbi.nlm.nih.gov/pubmed/21146207

2. Denkinger CM, Grant AD, Denkinger M, Gautam S, D'Agata EMC. Increased multi-drug resistance among the elderly on admission to the hospital-a 12-year surveillance study. Arch Gerontol Geriatr [Internet]. 2013 [cited 2016 Oct 13];56:227-30. Available from: https://www.ncbi.nlm.nih.gov/pubmed/22682422

3. Kaye KS, Marchaim D, Chen TY, Baures T, Anderson DJ, Choi Y, et al. Effect of nosocomial bloodstream infections on mortality, length of stay, and hospital costs in older adults. J Americ Geriatr Soc [Internet]. 2014 [cited 2016 Oct 13];62:306-11. Available from: https://www.ncbi.nlm.nih.gov/pubmed/24438554

4. Sousa MAS, Lima TR, Sousa AFL, Carvalho MM, Brito GMI, Camilotti A. Prevalence of bloodstream infection in hospitalized elderly in a General Hospital. Rev Pre Infec Saúde [Internet]. 2015 [cited 2016 Oct 13];1(3):11-17. Available from: http://www. academia.edu/19827318/Prevalence_of_bloodstream_infection_in_hospitalized_elderly_in_a_General_Hospital

5. Padoveze MC, Fortaleza CMCB. Healthcare-associated infections: challenges to public health in Brazil. Rev Saúde Pública [Internet]. 2014 [cited 2016 Oct 13];48(6):995-1001. Available from: http://www.scielo.br/pdf/rsp/v48n6/0034-8910-rsp-48-6-0995.pdf

6. Avci M, Ozgenc O, Coskuner SA. Hospital acquired infections (HAI) in the elderly: Comparison with the younger patients. Arch Gerontol Geriatr [Internet]. 2012 [cited 2016 Oct 13];54:247-50. Available from: https://www.ncbi.nlm.nih.gov/ pubmed/21529974

7. Dimopoulos G, Koulenti D, Blot S, Sakr Y, Anzueto A, Spies C, et al. Critically ill elderly adults with infection: analysis of the extended prevalence of infection in intensive care study. J Americ Geriat Soc [Internet]. 2013 [cited 2016 Oct 13];61(12):2065-71. Available from: https://www.ncbi.nlm.nih.gov/pubmed/24479140

8. USA. Centers for Disease Control and Prevention-CDC. CDC/NHSN Surveillance Definitions for Specific Types of Infections [Internet]. 2016 [cited 2016 Jun 24]. Available from: http://www.cdc.gov/nhsn/pdfs/pscmanual/17pscnosinfdef_current.pdf

9. Agência Nacional de Vigilância Sanitária- ANVISA. Critérios Diagnósticos de Infecção Relacionada à Assistência à Saúde [Internet]. 2013 [cited 2016 Jun 24];(2). Available from: http://www20.anvisa.gov.br/segurancadopaciente/images/documentos/ livros/Livro2-CriteriosDiagnosticosIRASaude.pdf

10. Li Q. A novel Likert scale based on fuzzy sets theory. Expert Syst Appl [Internet]. 2013 [cited 2016 Oct 13];40 (5):1609-18. Available from: http://www.sciencedirect.com/science/article/pii/S095741741201069X

11. Rothan-Tondeur MK, Chami K, Pollet C. Infections in the elderly in long-term care facilities. Soins Gerontol [Internet]. 2011 [cited 2016 Oct 13];(92):20-3. Available from: https://www.ncbi.nlm.nih.gov/pubmed/22288274

12. Kaplan V, DC Angus, MF Griffin. Hospitalized community-acquired pneumonia in the elderly. Am J Respir Crit Care Med [Internet]. 2002 [cited 2016 Oct 13];165:766-72. Available from : https://www.ncbi.nlm.nih.gov/pubmed/11897642

13. Lesthaeghe R. The second demographic transition: a concise overview of its development. PNAS [Internet]. 2014 [cited 2016 Oct 13];111(51):18112-5. Available from: http://www.pnas.org/content/111/51/18112.full.pdf

14. Fuchs L, Chronaki CE, Park S, Novack V, Baumfeld Y, Scott D, et al. ICU admission characteristics and mortality rates among elderly and very elderly patients. Intensive Care Med [Internet]. 2012 [cited 2016 Oct 13];38(10):1654-61. Available from: https:// www.ncbi.nlm.nih.gov/pubmed/22797350

15. Becker S, Müller J, de Heer G, Braune S, Fuhrmann V, Kluge S. Clinical characteristics and outcome of very elderly patients $\geq 90$ years in intensive care: a retrospective observational study. Ann Intensive Care [Internet]. 2015 [cited 2016 Oct 13];5:53. Available from: https://www.ncbi.nlm.nih.gov/pmc/articles/PMC4686461/.

16. Heyland D, Cook D, Bagshaw SM, Garland A, Stelfox HT, Mehta S, et al. The Very Elderly Admitted to ICU: A Quality Finish? Crit Care Med [Internet]. 2015 [cited 2016 Oct 13];43(7):1352-60. Available from : https://www.ncbi.nlm.nih.gov/pubmed/25901550

17. Gonzales JER, Obregón JS, Dal Gesso CM, Culebradas PG, Sanchez SS, Torralba M. Influence of orotracheal intubation, shock and acute renal failure of elderly patients admitted to ICU. Intensive Care Med Exp [Internet]. 2015 [cited 2016 Oct 13];3(Suppl 1):A658. Available from: https://www.ncbi.nlm.nih.gov/pmc/articles/PMC4797094/.

18. Kaye KS, Marchaim D, Chen TY, Baures T, Anderson DJ, Choi Y, et al. Effect of nosocomial bloodstream infections on mortality, length of stay, and hospital costs in older adults. J Am Geriatr Soc [Internet]. 2014 [cited 2016 Oct 13];62(2):306-11. Available from: https://www.ncbi.nlm.nih.gov/pubmed/24438554

19. Cei M, Bartolomei C, Mumoli N. In-hospital mortality and morbidity of elderly medical patients can be predicted at admission by the Modified Early Warning Score: a prospective study. Int J Clin Pract [Internet]. 2009 [cited 2016 Oct 13];63(4):591-5. Available from: https://www.ncbi.nlm.nih.gov/pubmed/19220521

20. Sprung CL, Artigas A, Kesecioglu J, Pezzi A, Wiis J, Pirracchio R, et al. The Eldicus prospective, observational study of triage decision making in European intensive care units. Part II: intensive care benefit for the elderly. Crit Care Med [Internet]. 2012 [cited 2016 Oct 13];40(1):132-8. Available from: https://www.ncbi.nlm.nih.gov/pubmed/22001580 
21. Liang SY, Mackowiak PA. Infections in the elderly. Clin Geriatr Med [Internet]. 2007 [cited 2016 Oct 13];23(1):441-56. Available from: https://www.ncbi.nlm.nih.gov/pubmed/17462528

22. Steens A, Eriksen HM, Blystad H. What are the most important infectious diseases among those $\geq 65$ years: a comprehensive analysis on notifiable diseases, Norway, 1993-2011. BMC Infect Dis [Internet]. 2014 [cited 2016 Oct 13];14:57. Available from: http://bmcinfectdis.biomedcentral.com/articles/10.1186/1471-2334-14-57

23. Guimarães C, Santos CL, Costa F, Barata F. Pneumonia associated with health care versus community acquired pneumonia: different entities, distinct approaches. Rev Port Pneumol [Internet]. 2011 [cited 2016 Oct 13];17(4):168-71. Available from: http:// www.sciencedirect.com/science/article/pii/S087321591100002X

24. Gavazzi G, Delerce E, Cambau E, François P, Corroyer B, Wazières B, et al. Diagnostic criteria for urinary tract infection in hospitalized elderly patients over 75 years of age: a multicenter cross-sectional study. Med Mal Infect [Internet]. 2013 [cited 2016 Oct 13];43(5):189-94. Available from : https://www.ncbi.nlm.nih.gov/pubmed/23622951

25. Foxman B. Urinary tract infection syndromes: occurrence, recurrence, bacteriology, risk factors, and disease burden. Infect Dis Clin North Am [Internet]. 2014 [cited 2016 Oct 13];28(1):1-13. Available from: https://www.ncbi.nlm.nih.gov/pubmed/24484571

26. Mody L, Manisha JM. Urinary tract infections in older women: a clinical review. JAMA [Internet]. 2014 [cited 2016 Oct 13];311(8):844-54. Available from: https://www.ncbi.nlm.nih.gov/pubmed/24484571

27. Murea M, James KM, Russell GB, Byrum GV, Yates JE, Tuttle NS, et al. Risk of catheter-related bloodstream infection in elderly patients on hemodialysis. Clin J Am Soc Nephrol [Internet]. 2014 [cited 2016 Oct 13];9(4):764-70. Available from: https://www. ncbi.nlm.nih.gov/pubmed/24651074

28. Blot S, Cankurtaran M, Petrovic M, Vandijck D, Lizy C, Decruyenaere J, et al. Epidemiology and outcome of nosocomial bloodstream infection in elderly critically ill patients: a comparison between middle-aged, old, and very old patients. Crit Care Med [Internet]. 2009 [cited 2016 Oct 13];37(5):1634-41. Available from: https://www.ncbi.nlm.nih.gov/pubmed/19325489

29. Nosrati M, Boroumand M, Tahmasebi S, Sotoudeh M, Sheikhfathollahi M, Goodarzynejad H. Excess costs associated with common healthcare-associated infections in an Iranian cardiac surgical unit. J Hosp Infect [Internet]. 2010 [cited 2016 Oct 13];76(4):304-7. Available from: https://www.ncbi.nlm.nih.gov/pubmed/20833445

30. Mocanu V, Buth KJ, Johnston LB, Davis I, Hirsch GM, Légaré JF. The importance of continued quality improvement efforts in monitoring hospital-acquired infection rates: a cardiac surgery experience. Ann Thorac Surg [Internet]. 2015 [cited 2016 Oct 13];99(6):2061-9. Available from: https://www.ncbi.nlm.nih.gov/pubmed/25795297 